\title{
Sistem Informasi Manajemen pada Toko Bangunan (Studi Kasus: TB Al-haidar Kabupaten Malang)
}

\author{
Mayank Angelin, Hendro Poerbo Prasetiya* \\ Program Studi Sistem Informasi, Universitas Ma Chung, J1. Villa Puncak Tidak N-01, \\ Malang, Indonesia 65151 \\ Correspondence: Hendro Poerbo P. (hendro.poerbo@machung.ac.id) \\ Received: 15 Agustus 2021 - Revised: 1 November 2021 - Accepted: 4 November 2021
}

\begin{abstract}
Abstrak. Toko Bangunan Al-haidar merupakan supermarket bahan bangunan yang menyediakan bahan bangunan seperti besi, galvalum, aluminium, alat-alat kelistrikan, alat-alat pertukangan, dan lain-lain. Semakin meningkatnya perkembangan TB Al-haidar sekarang ini mengharuskan toko tersebut mencatat lebih dari ribuan transaksi penjualan dalam setiap tahunnya sehingga menuntut pihak toko untuk dapat menyediakan layanan sistem informasi manajemen berbasis web guna menunjang transaksi penjualan dan pelayanan lebih baik. Metode pengembangan sistem yang digunakan dalam pengembangan sistem adalah metode Waterfall. Alat yang digunakan untuk menggambarkan model sistem adalah berupa Mind Mapping, Use Case, Workflow, diagram aktivitas, tabel skenario dan Mock Up serta dalam perancangan basis data menggunakan kamus data, dan Entity Relationship Diagram (ERD). Untuk mengimplementasikan sistem informasi sistem ini, dibutuhkan komponen pendukung agar dapat bekerja dengan baik. Komponen tersebut diantaranya menggunakan bahasa pemrograman PHP dan untuk penyimpanan data menggunakan database MySQL. Dengan adanya Sistem Informasi tersebut diharapkan dapat mempermudah pengolahan data dan pengolahan laporan.
\end{abstract}

Kata kunci: sistem, informasi, manajemen, sistem informasi manajemen, waterfall.

Citation Format: Angelin, M. \& Prasetiya, H.P. (2021). Sistem Informasi Manajemen pada Toko Bangunan (Studi Kasus: TB Al-haidar Kabupaten Malang). Prosiding Seminar Nasional Sistem Informasi dan Teknik Informatika (SAMA SISI), 44-60. 


\section{PENDAHULUAN}

Berdasarkan fenomena yang terjadi pada bisnis diberbagai bidang tidak terkecuali penjualan maupun pembelian, dapat digambarkan bahwa usaha pada bisnis perdagangan juga sangat membutuhkan dukungan dari bidang teknologi informasi untuk tetap dapat bertahan menghadapi persaingan pasar saat ini juga masa yang akan datang.

Bisnis yang bergerak pada bidang perdagangan seperti TB Al-haidar yang harus memperhatikan pengelolaan barang masuk sampai dengan barang terjual nantinya. Bisnis perdagangan ini harus didukung oleh sebuah sistem informasi yang dapat mengelola data pembelian serta data penjualan. Sistem informasi adalah suatu sistem dalam organisasi yang mempertemukan kebutuhan pengolahan transaksi harian, mendukung operasi, bersifat manajerial, kegiatan strategi dari suatu organisasi dan menyediakan pihak luar tertentu dengan laporan-laporan yang diperlukan (Jogiyanto, 2015). Informasi yang didapatkan merupakan data barang yang dibutuhkan pada sebuah bisnis di bidang perdagangan seperti TB Al-haidar yaitu pada bagian pembelian, penjualan, persediaan dan pencatatan keuangan.

Permintaan sistem informasi manajemen juga terdapat pada TB Al-haidar, perusahaan ini merupakan perusahaan mulai berkembang yang menjalankan usaha dagang bahan-bahan bangunan. Pada sistem yang berjalan pencatatan laporan pembelian, laporan penjualan, hutang dan piutang masih secara manual yaitu menggunakan nota pembelian yang ditulis tangan dan nota hutang serta nota piutang akan akan di arsip pada lemari kasir. Media penyimpanan data masih menggunakan kertas nota dan buku sebagai arsip, sehingga berdampak pada kinerja pelayanan dan menyebabkan terjadinya resiko kehilangan data karna arsip hanya bergantung pada nota yang ada.

Berdasarkan permasalahan yang terjadi maka dirancanglah sebuah sistem informasi manajemen. Sistem Informasi Manajemen atau SIM adalah suatu sistem berbasis komputer yang membuat informasi tersedia bagi para pengguuna yang memiliki kebutuhan serupa. (McLeod, Jr., Raymond; Schell, 2011). Sistem informasi manajemen yang dibutuhkan oleh TB Al-haidar adalah SIM yang mampu menampilkan laporan pembelian, laporan penjualan, laporan produksi, laporan persediaan, pencatatan hutang dan piutang. Serta arsip akan tersimpan dengan lebih aman dan terstruktur juga lebih mudah dalam pencarian data karena disimpan kedalam database. Secara umum database atau dalam bahasa Indonesia berarti Basis Data merupakan kumpulan informasi yang disimpan di dalam 
komputer secara sistematik sehingga dapat diperiksa menggunakan suatu program komputer.(termasmedia, 2017)

\section{METODE PELAKSANAAN}

Menurut (Pressman, R.S. \& Maxim, B.R. 2015) model waterfall disebut juga sebagai classic life cycle, menganjurkan sebuah sistematik, pendekatan sekuensial untuk pengembangan piranti lunak yang dimulai dengan spesifikasi dari kebutuhan pelanggan dan proses-proses melalui perencanaan, pemodelan, konstruksi, dan peluncuran, memuncak pada bantuan yang sedang berjalan dari penyelesaian suatu piranti lunak.

Pengembangan sistem dimulai dari analisis kebutuhan pengguna dan sistem. Analisis kebutuhan pada penelitian ini diperoleh dengan mengumpulkan data melalui wawancara dengan pemilik toko. Selanjutnya dapat diketahui data yang dibutuhkan, untuk selanjutnya dilakukan pengumpulan data sesuai kebutuhan. Langkah berikutnya akan dilakukan perancangan sistem berdasarkan data yang diperoleh. Perancangan atau desain mockup dilakukan sebelum melakukan pembangunan sistem guna sebagai acuan dalam pembangunan sistem nantinya. Kemudian akan dilanjutkan dengan pembangunan sistem informasi manajemen TB Al-haidar. Berikutnya yaitu dilakukan testing untuk kemudian dilakukan penyerahan sistem pada TB Al-haidar.

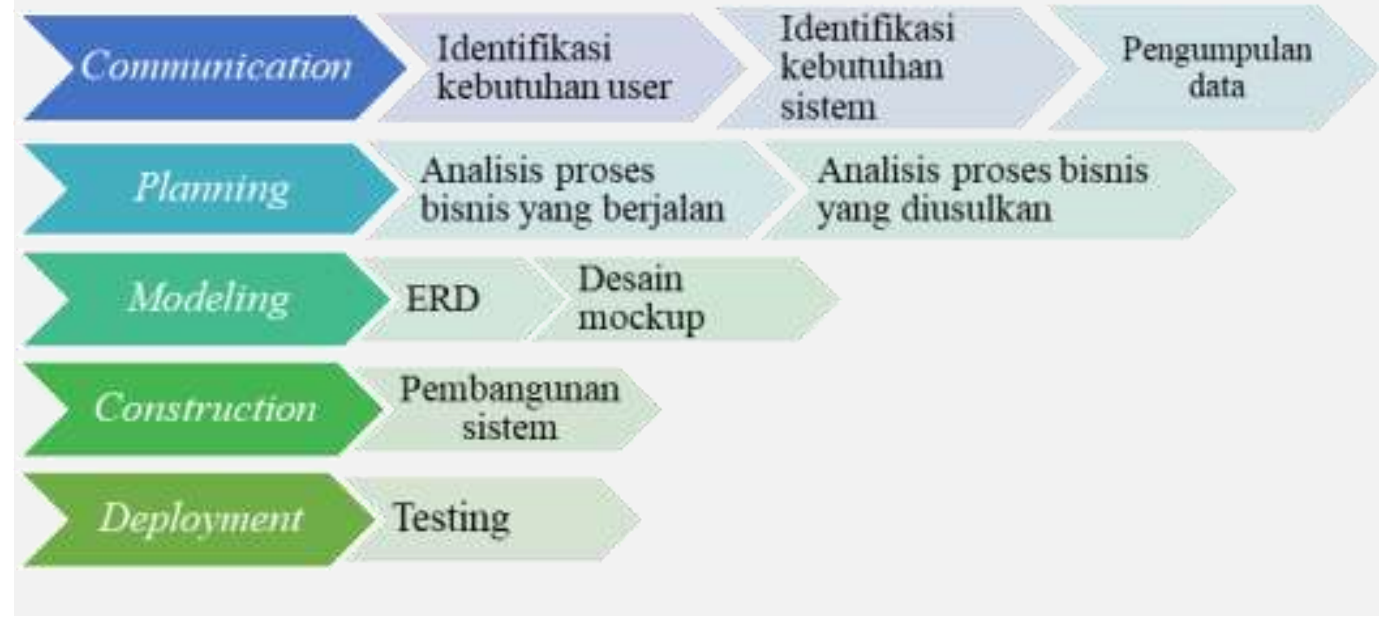

Gambar 1. Metode pengerjaan waterfall. 


\section{a. Communication}

Pada langkah communication merupakan langkah untuk mendapatkan data yang dibutuhkan nantinya dalam membangun sistem. Langkah awal dimulai dari identifikasi kebutuhan user kemudian identifikasi kebutuhan sistem untuk selanjutnya dilakukan pengumpulan data guna membangun sistem sesuai kebutuhan pengguna dan sistem.

b. Planning

Pada tahap perencanaan, tim memperkirakan setiap detil yang dibutuhkan dalam pembuatan proyek, penjadwalan dan pelacakan terhadap proses yang sedang berjalan. desain yang ada pada tahapan ini yaitu desain mindmap, use case beserta penjelasan pembagian hak akses, diagram aktivitas use case beserta tabel skenario, gambaran proses bisnis yang sedang berjalan serta proses bisnis yang diusulkan

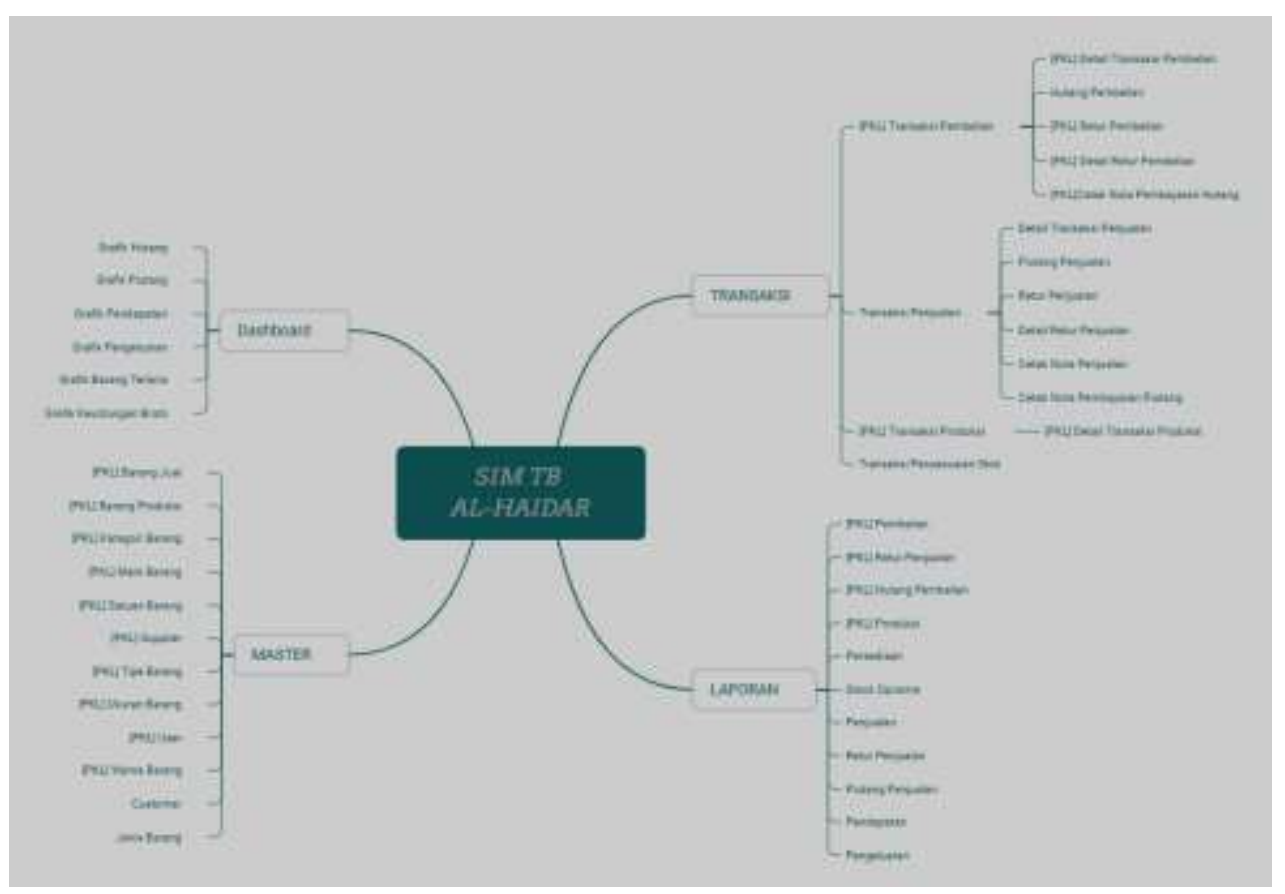

Gambar 2. Desain mindmap Sistem Informasi Manajemen TB Al-haidar.

c. Modeling

Pada tahap ini, dilakukan analisa dan pemodelan, berikut pembuatan desain, sesuai dengan kebutuhan proyek. Pada bagian ini akan dirancang sebuar ERD. Entity Relationship Diagram (ERD) merupakan diagram yang berupa notasi grafis dalam pemodelan data konseptual menggambarkan hubungan antara penyimpan satu dengan yang lain (Dosen Online, 2017) 


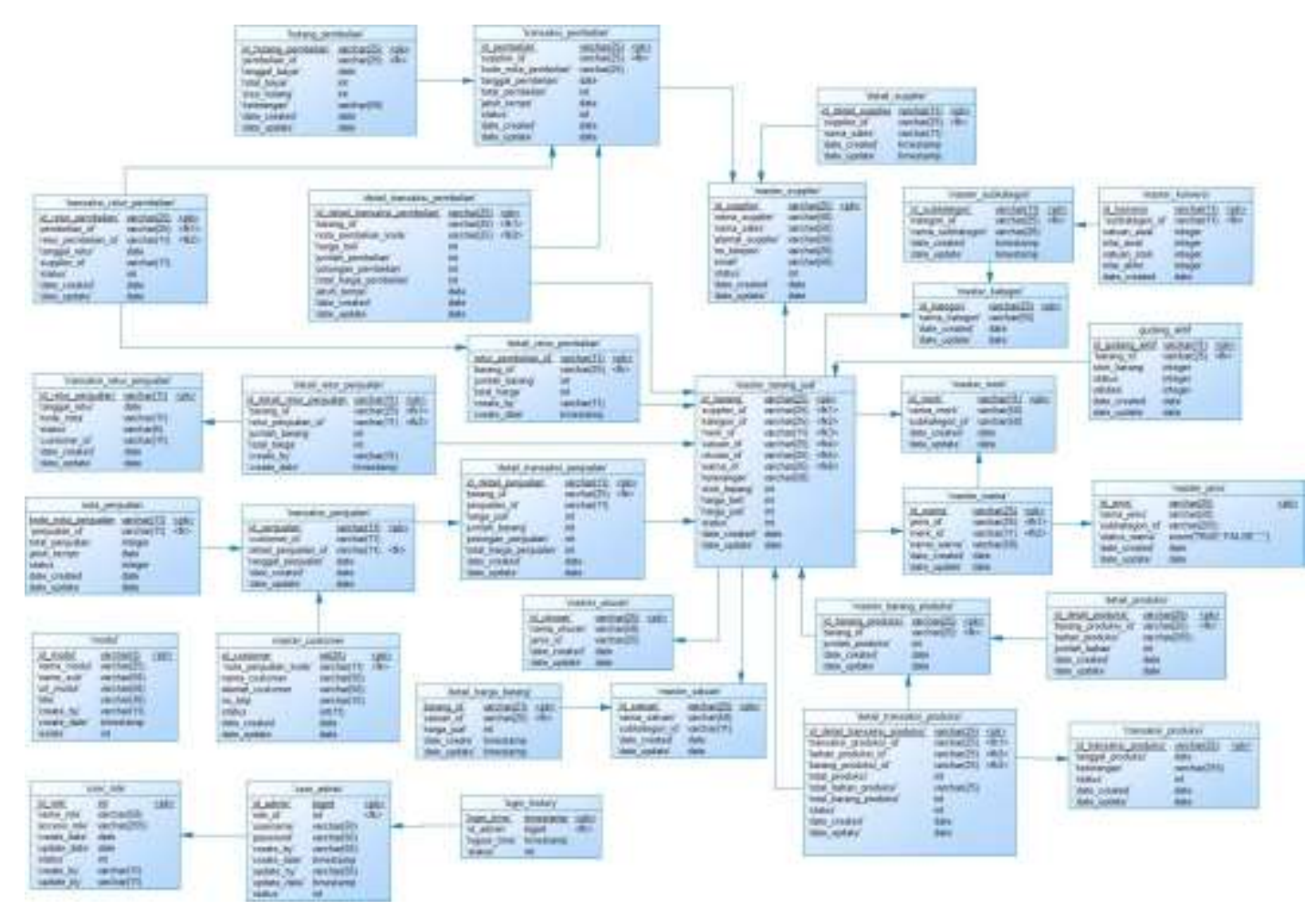

Gambar 3. Entity relationship diagram SIM TB Al-haidar.

d. Construction

Di tahap berikut ini, tim melakukan konstruksi pembuatan kode-kode guna membangun proyek, serta melakukan percobaan pada prototipe proyek. Pada tahap konstruksi ini perangkat lunak yang digunakan adalah :

1. Pre-Hypertext Processor (PHP) adalah salah satu bahasa pemrograman yang berjalan dalam sebuah webserver dan berfungsi sebagai pengolah data pada sebuat server. (Andi dan MADCOMS, 2011a)

2. MySQL adalah salah satu basis data untuk server, jenis basis data ini sangat populer dan digunakan pada banyak website di internet sebagai bank data dari sistem informasi mereka. (Andi dan MADCOMS, 2011b) 
3. Javascript, adalah bahasa scripting yang popular di internet dan dapat bekerja di sebagian besar browser popoler Kode Javascript dapat disisipkan dalam halaman web menggunakan tag SCRIPT. (Sunyoto, 2007)

4. Cascading Style Sheet (CSS) Styles atau tampilan yang dimaksud mempengaruhi bagaimana elemen pada HTML direpresentasikan. (W3Schools, 2014)

5. PhpMyAdmin, sebuah aplikasi Open Source yang berfungsi untuk memudahkan manajemen MySQL. (MADCOMS, 2016).

6. XAMPP XAMPP merupakan software gabungan dari beberapa software lainnya dengan fungsi yang sama yakni menunjang pembuatan web dengan menyediakan web server lokal yang dapat ditanamkan pada PC atau laptop..(Hermawan, 2019)

7. Sublime Text,Sublime Text adalah aplikasi editor untuk kode dan teks yang dapat berjalan diberbagai platform operating system dengan menggunakan teknologi Phyton API. (M.Faridi, 2015)

e. Deployment

Pada tahap ini, dilaksanakannya penyampaian produk pada pelanggan, menyediakan bantuan kepada para pengguna, dan pengumpulan umpan balik demi memperbaiki dan memperbagus produk terkait.

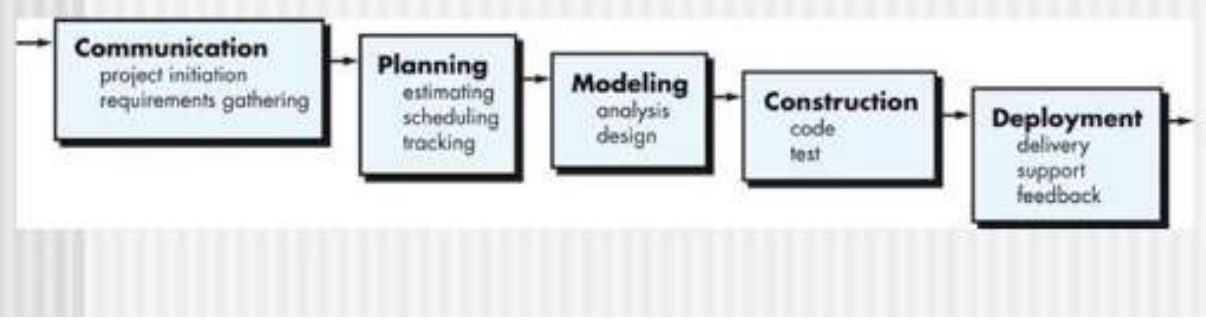

Gambar 4. Tahapan metode waterfall.

\section{HASIL DAN PEMBAHASAN}

Sebelum dapat melihat hasil pengembangan sistem, maka harus dilakukan instalasi program/aplikasi pada perangkat keras yang dapat mendukung untuk menjalankann sistem informasi yang dikembangkan. Selain perangkat keras, juga dibutuhkan perangkat lunak yang sesuai dengan ketentuan yang dibutuhkan untuk instalasi memasang program aplikasi 
pada perangkat keras yang disediakan. Spesifikasi perangkat keras dan perangkat lunak yang diperlukan akan dibahas lebih lanjut pada subbab berikut.

1. Kebutuhan Perangkat Keras

Perangkat keras yang dibutuhkan untuk memasang Sistem Informasi Pembelian dan Pencatatan Hutang Toko Bangunan Al-haidar adalah sebagai berikut.

Tabel 1. Spesifikasi perangkat keras pengembangan sistem.

\begin{tabular}{ccc}
\hline No. & Perangkat & Spesifikasi Minimum \\
\hline 1. & Mouse & Optical Mouse \\
2. & Keyboard & USB Keyboard \\
4. & Printer & Inkjet \\
5. & Processor & Intel Core i3 \\
6. & RAM & $2 \mathrm{~GB}$ \\
7. & Hardisk & $500 \mathrm{~GB}$ \\
8. & Monitor & 14" LED Display \\
\hline
\end{tabular}

2. Kebutuhan perangkat lunak

Perangkat lunak yang dibutuhkan untuk menginstalasi Sistem Informasi Pembelian dan Pencatatan Hutang Toko Bangunan Al-haidar pada perangkat keras yang disarankan diatas adalah dengan menggunakan beberapa perangkat lunak yang terinstal didalamnya, yaitu sebagai berikut.

Tabel 2. Spesifikasi kebutuhan perangkat lunak.

\begin{tabular}{cll}
\hline No. & \multicolumn{1}{c}{ Aplikasi } & \multicolumn{1}{c}{ Spesifikasi } \\
\hline 1. & Sistem Operasi & Windows 7 \\
2. & Aplikasi Database & XAMPP \\
4. & Browser & Google Chrome \\
5. & Aplikasi Pemrograman & Sublime Text \\
& Web & \\
6. & Aplikasi Pengolah Angka & Microsoft Excel \\
\hline
\end{tabular}

3. Cara instalasi sistem informasi

Pastikan ketika hendak melakukan instalasi sistem informasi, perangkat keras yang hendak dipergunakan sudah tersedia, dan perangkat lunak yang menjadi spesifikasi instalasi sudah terinstal pada perangkat keras.

a. Menjalankan aplikasi XAMPP, seperti pada gambar berikut. 


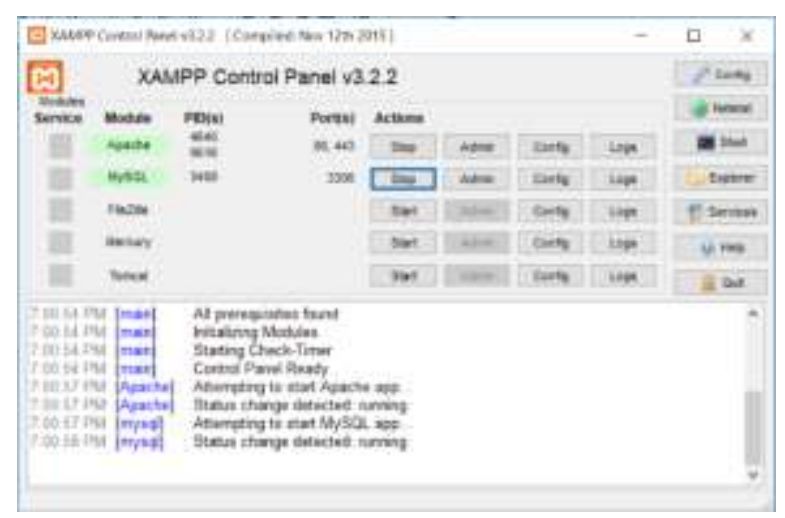

Gambar 5. Modul yang diaktifkan pada XAMPP.

b. Menyalin file Sistem Informasi pada direktori terinstallnya XAMPP, yaitu C:Ixampp2ไhtdocslalhaidar

c. Membuka halaman browser pada Google Chrome, kemudian mengetikkan http://localhost/alhaidar/ pada pencarian alamat.

d. Sistem Informasi Manajemen Toko Bangunan Al-haidar akan terbuka yaitu pada halaman Login.

4. Alur proses sistem informasi manajemen Toko Bangunan Al-haidar.

Pada bab ini membahas hasil dari pembangunan Sistem Informasi Manajemen pada Toko Bangunan Al-haidar berbasis web. Sistem ini menggunakan tiga hak akses, yaitu admin/pemilik (pemimpin perusahaan), kasir dan gudang. Alur proses bisnis sistem juga akan dijelaskan secara jelas untuk mengetahui alur berjalannya setiap transaksi yang ada pada sistem informasi manajemen.

Halaman login

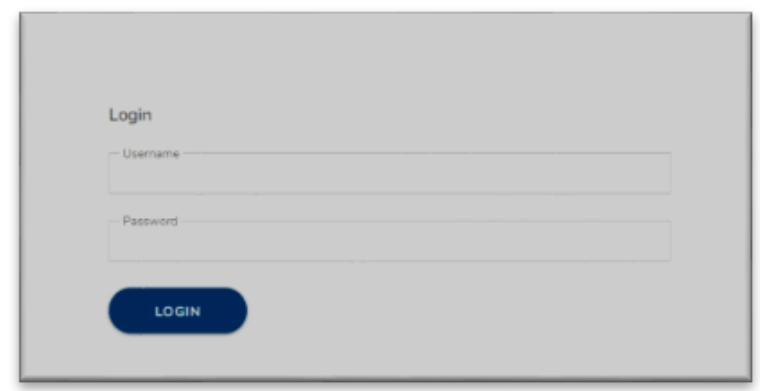

Gambar 6. Halaman login SIM TB Al-haidar. 
Pada halaman login terdapat dua inputan yang harus diisikan yaitu username dan password. Apabila ada kesalahan username atau password, sistem akan memberikan peringatan bahwa ada kesalahan input data.

\section{Halaman dashboard}

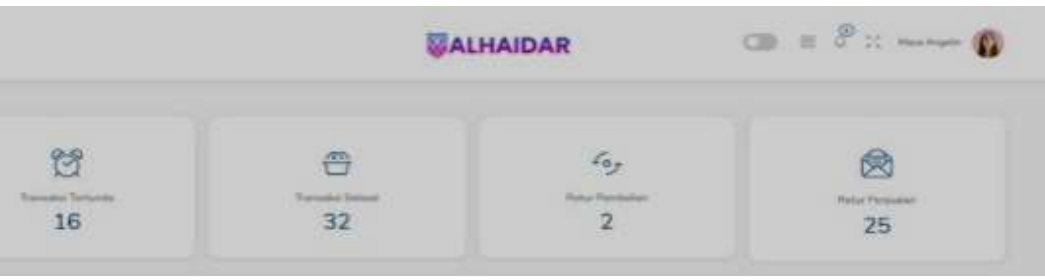

Gambar 7. Tampilan dashboard SIM TB Al-haidar.

Halaman dashboard merupakan halaman utama setelah dilakukan login. Pada halaman ini terdapat beberapa grafik seperti grafik pembelian, penjualan, kas masuk dan kas keluar, hutang dan piutang, juga terdapat informasi transaksi tertunda, stok menipis, transaksi hari ini, transaksi selesai, retur pembelian dan retur penjualan. Grafik diatas menampilkan informasi transaksi tertunda, transaksi selesai, retur pembelian dan retur penjualan.

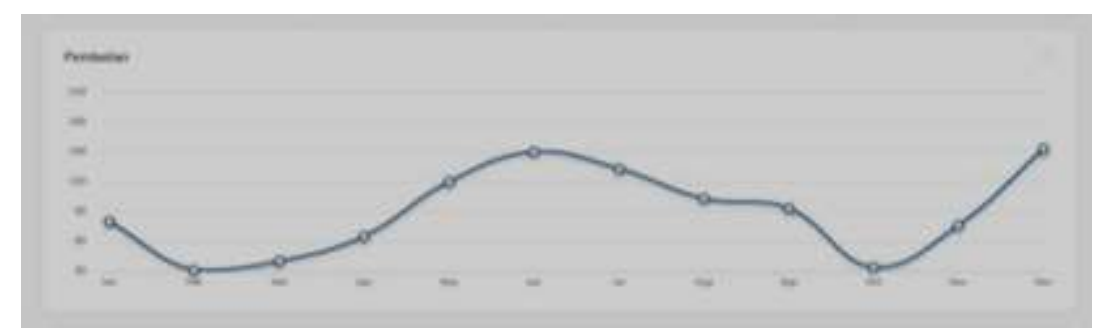

Gambar 8. Grafik pembelian.

Gambar 8 merupakan grafik pembelian dari sistem informasi manajemen TB Al-haidar. Grafik pembelian ini menampilkan data pembelian dengan periode satu bulan dengan nilai juta.

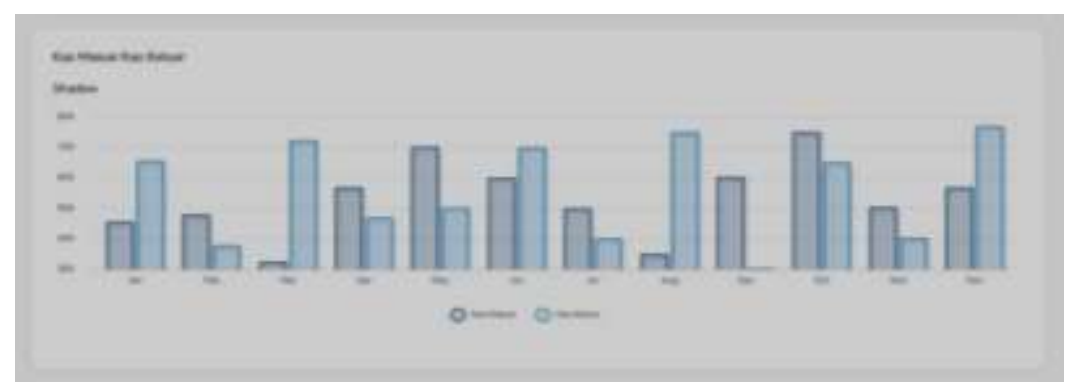

Gambar 9. Grafik kas masuk dan kas keluar. 
Gambar 9 merupakan grafik dari kas masuk dan kas keluar dengan periode per bulan. Dimana tampilan dashboard ini kas masuk di-ambil dari data transaksi penjualan yang sudah diterima dan kas keluar diambil dari data pembelian yang sudah dibayarkan.

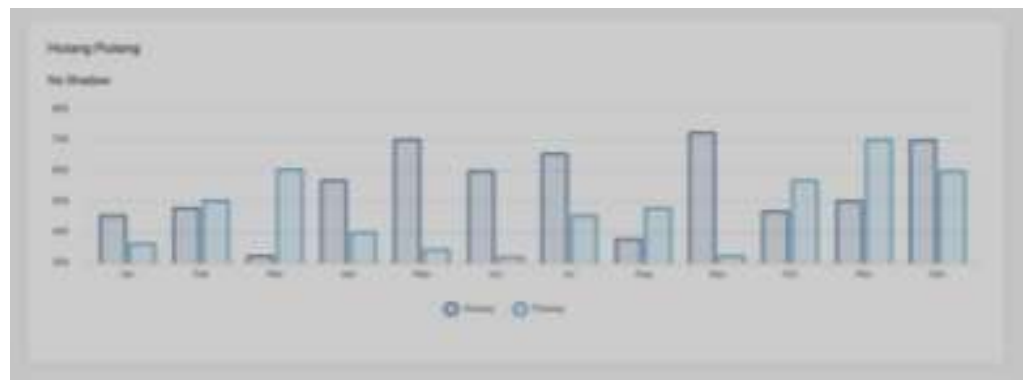

Gambar 10. Tampilan diagram hutang piutang.

Gambar 10 merupakan tampilan dari grafik hutang dan piutang yang ditampilkan berdasarkan periode per bulan. Dimana tampilan dashboard ini hutang diambil dari data pembelian dan piutang diambil dari data penjualan.

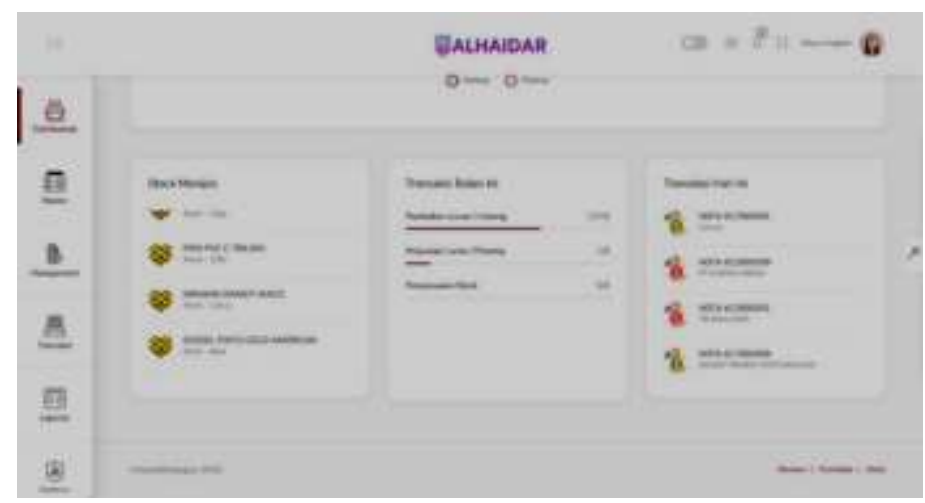

Gambar 11. Tampilan grafik stock dan transaksi.

Gambar 11 merupakan tampilan grafik stock dan transaksi. Dimana stock menipis menampilkan barang-barang yang kurang dari ketentuan cukup, ketentuan cukup tiap barag berbeda. Untuk semen minimal barang 50, cat 20 pcs, dll. Transaksi bulan ini memunculkan banyaknya transaksi ]yang telah dilakukan dalam satu bulan dan transaksi hari ini menampilkan transaksi yang dilakukan dalam hari dengan menampilkan kode nota transaksi. 
Menu master:

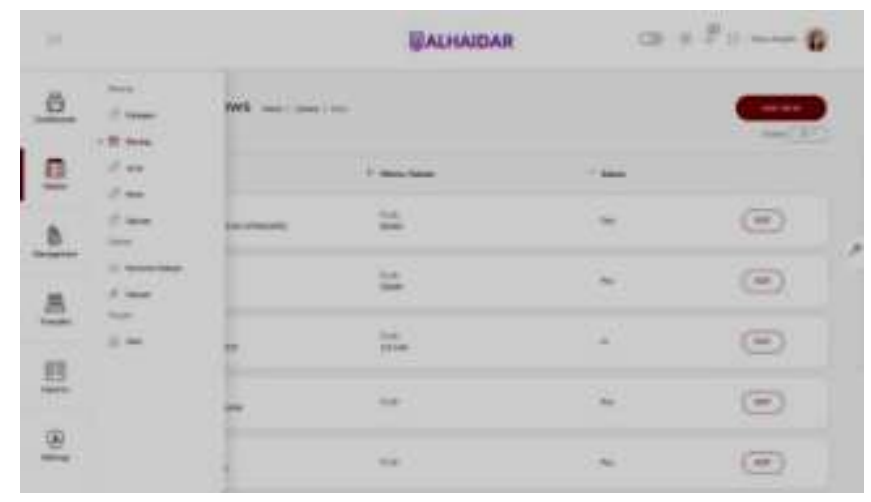

Gambar 12. Left menu master

Gambar 12 merupkan left menu master dari SIM TB Al-haidar. Terdapat 8 master yang ditampilkan diantaranya yaitu kategori, barang, jenis, merk, ukuran, satuan, konversi satuan dan user. Data-data master yang ada nantinya digunakan untuk melakukan transaksi baik transaksi pembelian, transaksi penjulan, transaksi retur pembelian dan transaksi retur penjualan.

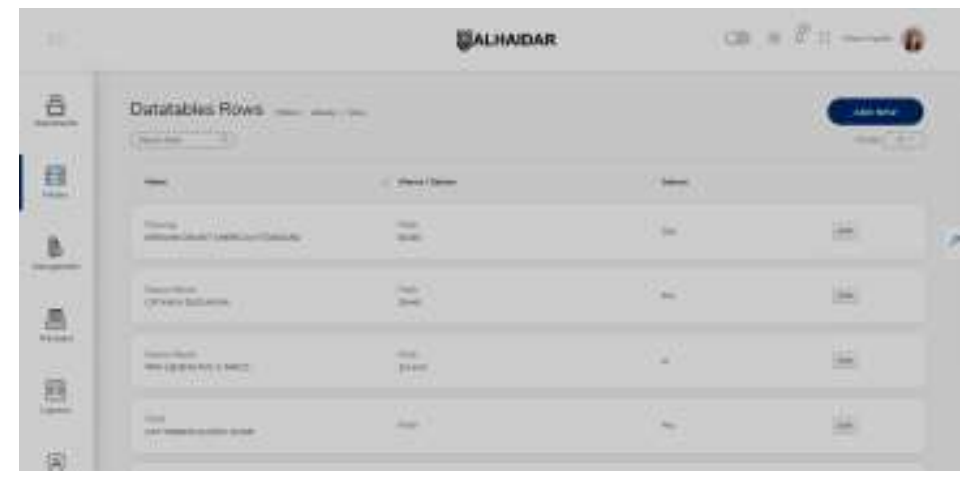

Gambar 13. Halaman master barang.

Halaman master barang digunakan untuk mengelola data barang yang akan digunakan dalam melakukan transaksi nantinya baik transaksi pembelian, penjualan bahkan transaksi retur. Pada halaman master barang menampilkan beberapa data diantaranya yaitu nama barang, warna/ukuran dan satuan. Pada halaman ini dapat dilakukan input dan edit data. 


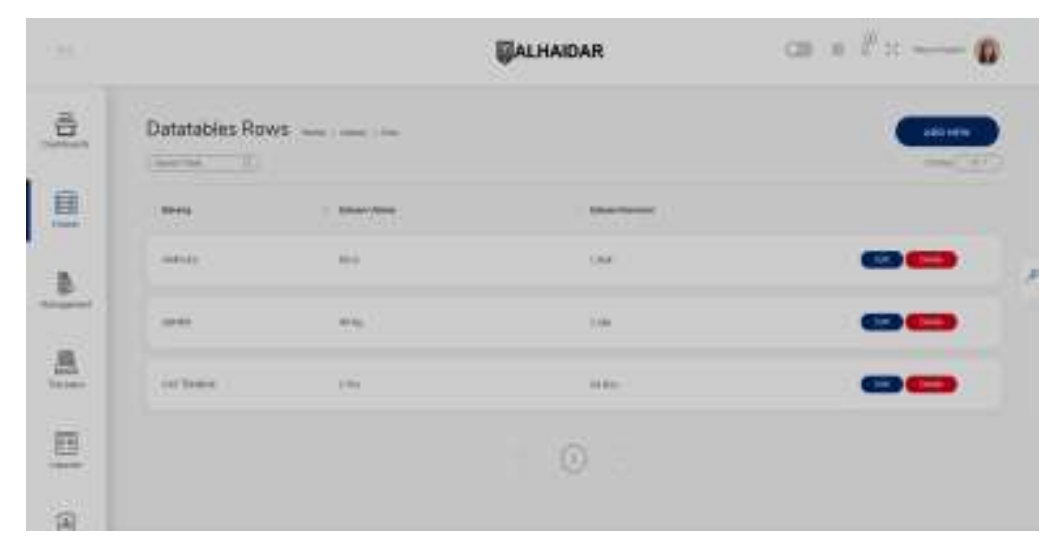

Gambar 14. Halaman master konversi satuan.

Pada halaman master konversi satuan dapat melakukan input data konversi satuan dengan cara "add new", setelah melakukan klik add new kemudian pilih barang yang akan dikonversi satuannya. Data yang harus diinputkan selanjutnya yaitu satuan utama dan nilai. Kemudian pilih satuan konversi dan input nilai.

\section{Menu management}

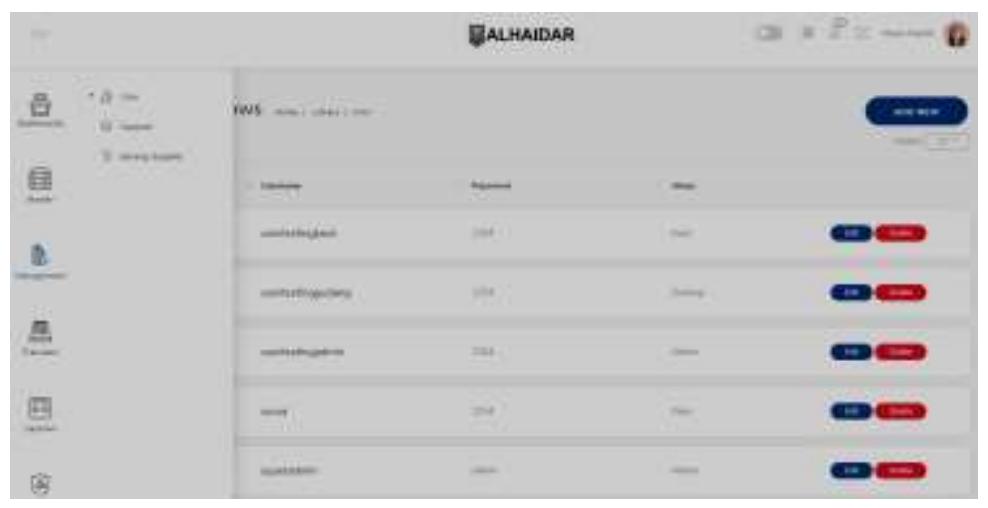

Gambar 15. Halaman management user

Pada halaman management user digunakan untuk mengelola data user pada sistem. Adapun data yang ditampilkan yaitu ID, username, password dan akses. Terdapat beberapa fungsi diantaranya tambah data baru dan edit. 


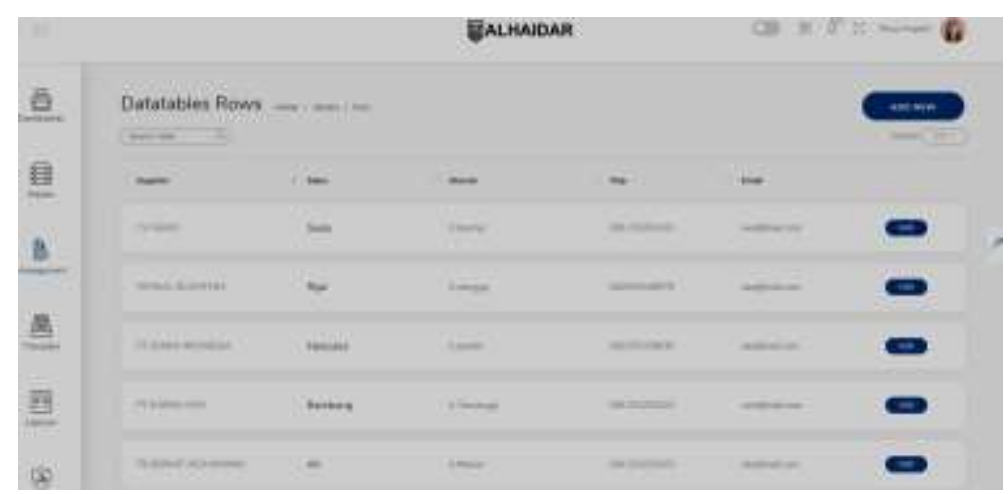

Gambar 16. Halaman mangement supplier.

Pada halaman management supplier digunakan untuk mengelola data supplier pada sistem informasi manajemen TB Al-haidar. Adapun data yang ditampilkan yaitu nama supplier, nama sales, alamat, telpon dan email. Terdapat beberapa button yang berfungsi diantarnyainput data baru data, search dan edit juga data yang ditampilkan dapat diatur berdasarkan nama supplier atau nama sales atau alamat atau no telpon atau email.

\section{Menu transaksi}

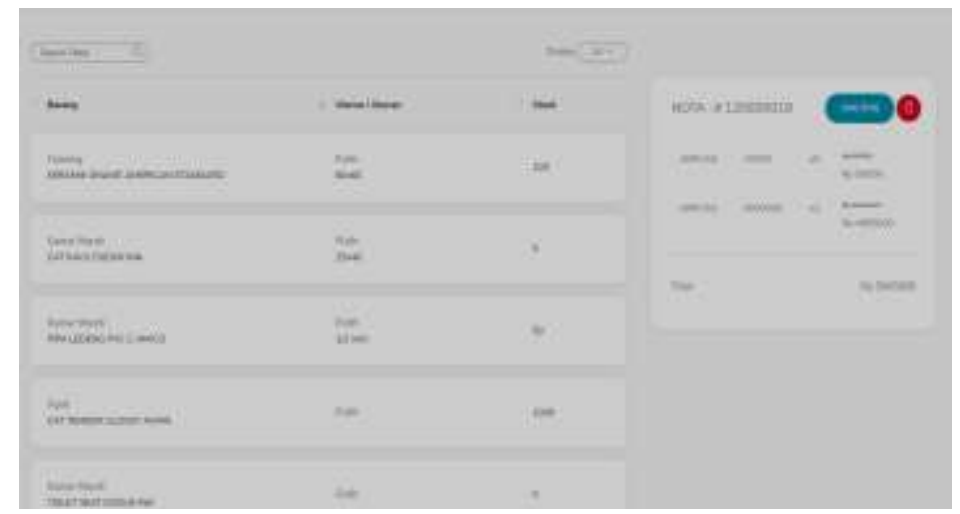

Gambar 17. Halaman transaksi pembelian.

Pada halaman transaksi pembelian digunakan untuk mengelola data transaksi pembelian. Data yang ditampilkan pada halaman ini berupa nama barang, warna/ukuran, stock dan nota pembelian. Detail dari barang dapat dilakukan dengan cara klik pada nama barang. 


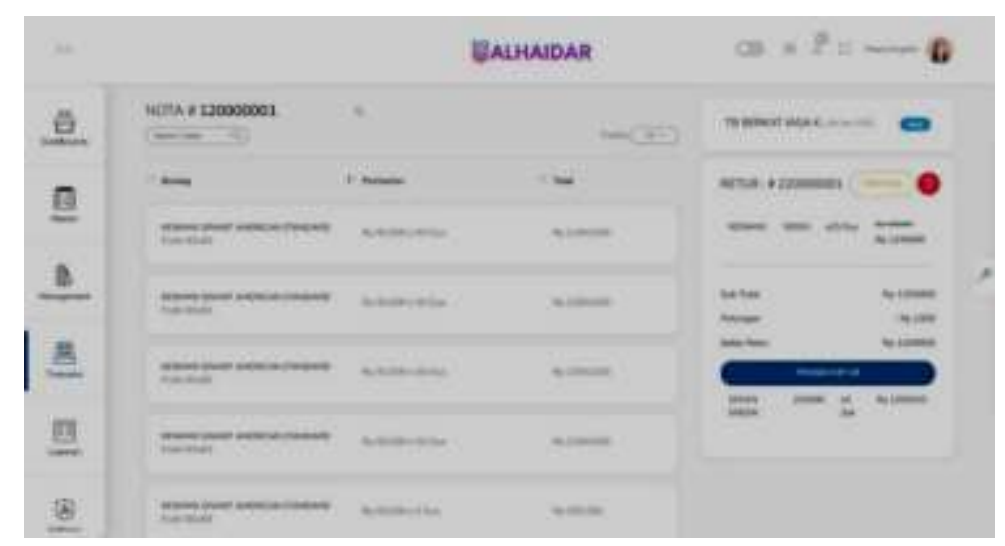

Gambar 18. Halaman transaksi retur pembelian

Halaman transaksi retur pembelian ini merupakan halaman yang digunakan untuk mengelola retur pembelian. Adapun data yang ditampilkan antara lain yaitu nama barang, warna, harga dan subtotal harga. Data dapat ditampilkan dengan cara melakukan input kode nota pembelian.

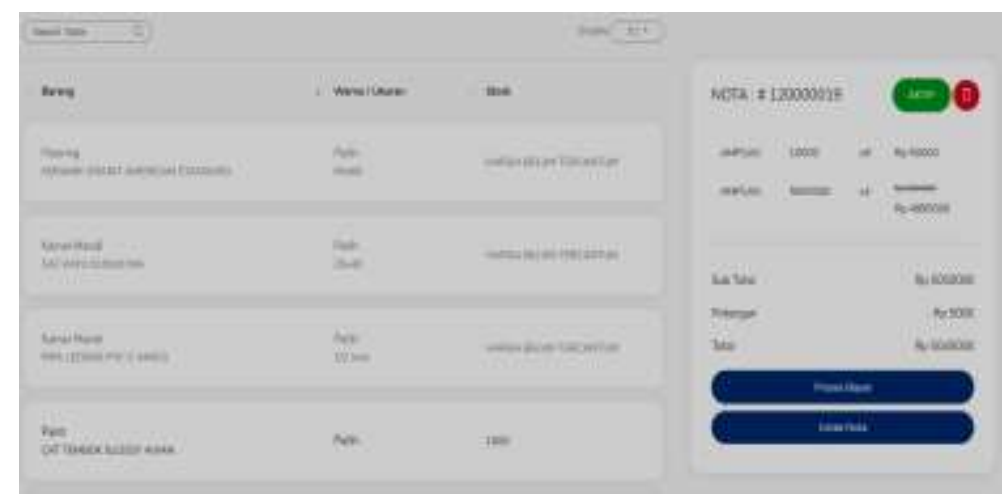

Gambar 19. Halaman transaksi penjualan

Halaman transaksi penjualan digunakan guna memproses transaksi penjualan untuk kemudianditampilkan nota dari transaksi penjualan. Data yang ditampilkan pada halaman ini yaitu nama barang, warna dan stok, juga terdapat search engine yang dapat digunakan untuk mencari data barang. Detail barang dapat dilihat dengan melakukan kli pada nama barang. 


\section{Menu laporan}

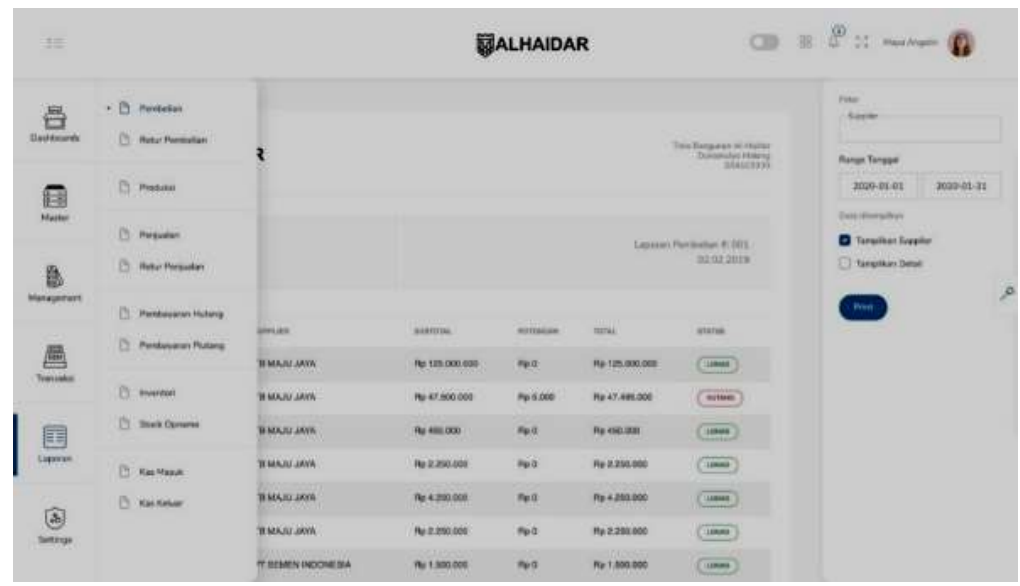

Gambar 20. Left menu laporan SIM TB Al-haidar.

Gambar 20 merupakan left menu dari laporan. Terdapat sebelas laporan pada halaman ini diantaranya laporan pembelian, retur pembelian, produksi, penjualan, retur penjualan, pembayaran hutang, pembayaran piutang, inventori, stock opname, kas masuk dan kas keluar. Laporan kas masuk diambil dari pembayaran yang telah dilakukan pada transaksi penjualan dan transaksi pembayaran piutang. Sedangkan kas keluar diambil dari pembayaran transaksi pembelian dan pembayaran hutang.

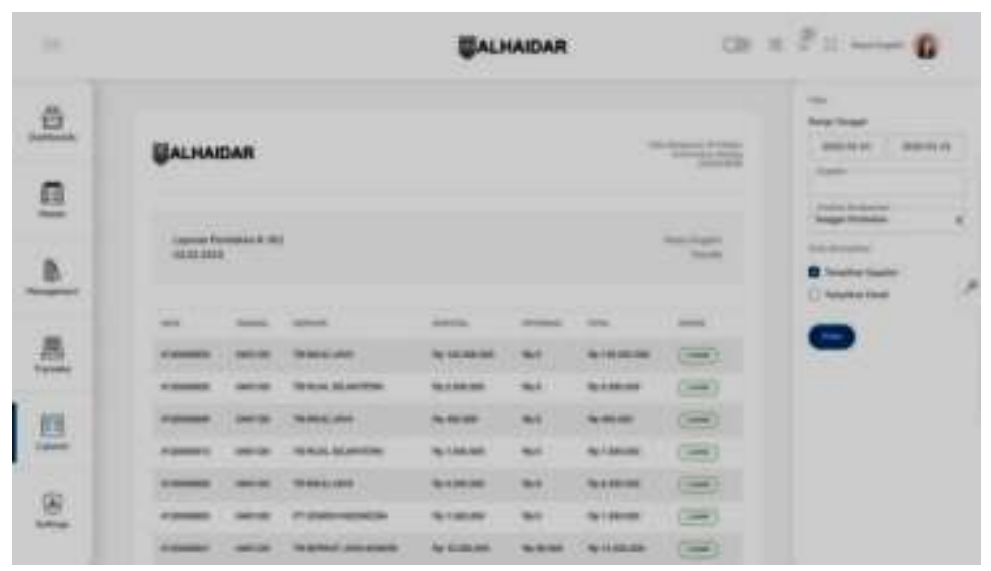

Gambar 21. Halaman laporan pembelian.

Pada halaman laporan pembelian menampilkan nota, tanggal, supplier, subtotal, potongan, total dan status. Untuk menampilkan halaman laporan pembelian ini dapat dilakukan dengan input filter tanggal. Halaman laporan juga terdapat fungsi yang dapat digunakan untuk melakukan print, menampilkan data berdasarkan, dan dapat menampilkan data supplier dan detail. 


\section{KESIMPULAN}

Sebelum menggunakan sistem informasi manajemen berbasis web TB Al-haidar masih menerapkan cara manual dalam setiap transaksi baik transaksi pembelian, transaksi penjualan, transaksi pembayaran hutang dan piutang, transaksi retur pembelian dan penjualan. Selain tidak bisa mendapatkan hasil laporan secara efektif dan efisien, cara yang konvensional dalam melakukan transaksi dan pencatatan sangat beresiko dengan munculnya kesalahan dari sisi manusia yang menjalankan sistem tersebut. Oleh karena itu, perusahaan ini membutuhkan sebuah sistem informasi manajemen berbasis web untuk diterapkan dalam kegiatan bisnis sehari-hari. Sistem ini dapat membantu TB Al-haidar untuk:

1) Meningkatkan efektifitas data dan transaksi dalam proses bisnis sehari-hari.

2) Mempercepat proses transaksi, dan meminimalisir kesalahan manusia.

3) Mencatat data paten sebagai master yang akan digunakan dalam transaksi.

4) Mencatat, mengolah, dan mengkalkulasi transaksi TB Al-haidar.

5) Menampilkan laporan pada periode tertentu.

\section{UCAPAN TERIMA KASIH}

1) Allah SWT, karena atas berkat dan rahmat-Nya penulis mendapatkan kekuatan dan ketabahan untuk menyelesaikan penelitian ini.

2) Kedua orang tua yang selalu memberikan dukungan selama proses pengerjaan penelitian ini.

3) Bpk. Hendro Poerbo Prasetiya, selaku Kepala Program Studi dan selaku Dosen Pembimbing yang bersedia untuk memberikan bimbingan dan membantu proses penyelesaian penelitian.

4) Rekan mahasiswa Sistem Informasi yang telah membantu dalam menyelesaikan beberapa permasalahan serta dukungan-dukungan lainnya baik secara moril maupun materil.

5) Ibu Dewi Ningsih dan Bapak Ashari, selaku pemilik Toko Bangunan Al-haidar yang telah memberikan izin untuk dapat melakukan pembangunan sistem informasi manajemen dengan studi kasus TB Al-haidar. 


\section{DAFTAR PUSTAKA}

Pressman, R.S. and Maxim, B.R. (2015) Software Engineering, A Practitioner's Approach Eighth Edition. New York.

Jogiyanto HM (2015) Analisis dan Desain Informasi: Pendekatan Terstruktur Teori dan Praktek Aplikasi Bisnis. Yogyakarta: C.V ANDI OFFSET.

McLeod, Jr., Raymond; Schell, G. P. (2011) Sistem Informasi Managemen (Terjemahan). jakarta: Salemba Empat.

Dosen Online (2017) Pengertian ERD (Entity Relationship Diagram) Menurut Para Ahli Belajar dan Berbagi, Gratis! Available at:

http://www.dosenonline.com/2017/01/pengertian-erd-entity-relationship-diagrammenurut-para-ahli.html (Accessed: 3 September 2019).

Andi \& MADCOMS (2011a) Aplikasi Web Database dengan Dreamweaver dan PHPMYSQL. Yogyakarta.

Andi dan MADCOMS (2011b) Aplikasi Web Database dengan Dreamweaver dan PHPMYSQL. Yogyakarta.

Sunyoto (2007) AJAX Membangun Web dengan Teknologi ASYNCHRONOUSE JAVASCRIPT \& XML. Yogyakarta.: Penerbit Andi.

termasmedia (2017) Pengertian Database, termasmedia.com. Available at: https://www.termasmedia.com/lainnya/software/69-pengertian-database.html (Accessed: 3 September 2019).

MADCOMS (2016) Pemrograman PHP dan MySQL untuk Pemula. Yogyakarta: andi.

W3Schools (2014) CSS Introduction, W3Schools.com. Available at: https://www.w3schools.com/css/css_intro.asp (Accessed: 3 September 2019)

Hermawan (2019) Pengertian XAMPP Beserta Fungsi dan Bagian-bagiannya (Lengkap), nesaba media. Available at: https://www.nesabamedia.com/pengertian-xampp (Accessed: 3 September 2019)

Faridi, M. (2015) Fitur Dahsyat Sublime Text 3. Surabaya: LUG

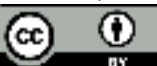

(C) 2021 by authors. Content on this article is licensed under a Creative Commons Attribution 4.0 International license. (http://creativecommons.org/licenses/by/4.0/). 